\title{
A Crustal-Upper-Mantle Model for the Colorado Plateau Based on Observations of Crystalline Rock Fragments in the Moses Rock Dike ${ }^{1}$
}

\author{
Thomas R. McGetchin \\ Department of Earth and Planetary Sciences, Massachusetts Institute of Technology \\ Cambridge, Massachusetts 02189
}

LEON T. SILVER

\begin{abstract}
Division of Geological Sciences, California Institute of Technology, Pasadena, California 91102
\end{abstract}
\begin{abstract}
On the basis of the size, the abundance, and the petrographic character of xenoliths in the Moses Rock dike, a model for the vertical stratigraphy of crystalline rocks beneath the dike is proposed extending from near the surface to a depth of about $200 \mathrm{~km}$. Sedimentary clasts, whose original position in the undisturbed vent walls is known but which are now within the intrusive breccia of the Moses Rock dike, show a decrease in size with distance of upward transport from their original position in the vent walls. This inverse relationship between fragment size and known depth of origin provides an empirical basis for a reconstructed model for the distribution of rocks on the basis of the particle size of fragments in the intrusive breccia. Metabasalt, granite, and granite gneiss are abundant in the upper part of the crust along the dike walls; diorite, gabbro, and amphibole schists of basic composition constitute intermediate layers, and garnet-bearing metagabbro (basic granulite gneiss) and serpentine schist are present in the lower crust. The crustal rock suite is predominantly metavolcanic and metaplutonic and basic in composition. Dense ultramafic rocks, possibly derived from the mantle, constitute about $0.3 \%$ of the breccia filling the dike and include jadeite-rich clinopyroxenite, eclogite, spinel-websterite, spinel-lherzolite, and garnet-lherzolite. The $\mathrm{M}$ discontinuity appraently occurs within a petrologically complex region and may coincide with phase and compositional transitions, which include hydration. A compositional transition within the upper mantle between spinel- and garnet-peridotite (lherzolite) is inferred. The variety and the abundance of ultramafic and dense types, together with the complexity of their textures, suggest that the mantle may be as complicated as the crust in composition and history.
\end{abstract}

Many workers have suggested that kimberlite pipes contain samples of deep-seated rocks apparently derived from vent walls over a wide vertical range extending into the earth's upper mantle. Ultramafic and eclogite xenoliths in basaltic rocks and kimberlite pipes have been studied with great interest as possible samples of the earth's upper mantle or lower crust [e.g., Forbes and Kuno, 1967; White, 1966; Jackson, 1968; Lovering and White, 1969; Wilshire and Binns, 1961; Williams, 1932; Dawson, 1962; Davidson, 1964; MacGregor and Carter, 1970; Watson, 1967; McGetchin, 1968; McGetchin

1 Division of Geological and Planetary Sciences, California Institute of Technology contribution 1919.

Copyright () 1972 by the American Geophysical Union. and Silver, 1968, 1970a, $b$; Helmstaedt and Anderson, 1969; Sobolev, 1970; and many others]. The emphasis historically has been on the petrology and the physical properties of these rocks, and only recently has attention been given to details of their field occurrence and distribution [Jackson, 1968; McGetchin, 1968; McGetchin and Silver, 1968, 1970b; Jackson and Wright, 1970]. Research on xenolithic fragments in volcanic rocks or breccia pipes has been concentrated on ultramafic and eclogite rocks (i.e., possible mantle-derived types), although in some cases, such as the kimberlite pipes, a diverse suite of rock fragments that may indicate extensive sampling from the intervening crustal layers as well occurs. These pipes are natural moholes, as was first fully recognized by Wagner [1928]. 
Because it has been shown that some minerals in the kimberlite at Moses Rock were probably in equilibrium at pressures equivalent to those at depths ranging between 100 and $200 \mathrm{~km}$ [McGetchin and Silver, 1970a], the crystalline fragments represent badly scrambled cuttings of a drill hole 100-200 km long. Field, chemical, petrographic, and microprobe data on the rocks and the mineral fragments in the dike, combined with knowledge of the local crust and uppermantle structure provided by refraction seismology, permit inferences to be made about the deep crust and upper mantle under the central Colorado plateau.

\section{Geological Setting and Petrological BACKground}

The Moses Rock dike is one of eight known kimberlite-bearing breccia-filled diatremes on the Colorado plateau. One cluster of diatremes occurs in the eastern Monument Valley area near the Arizona-Utah border and concentrated near the axis of the Comb ridge monocline (Figure 1), which forms the eastern margin of a large regional anticline, the Monument uplift. The location of the kimberlites may reflect structural control by the monocline.

The Moses Rock dike is a very-well-exposed 6-km-long hook-shaped breccia-filled intrusion paralleling the Comb ridge monocline. The dike has steeply dipping walls consisting of undeformed and unmetamorphosed red beds of the Permian Cutler formation. A system of joints in the vent walls parallels the dike contact.

The breccia filling in the dike varies, consisting mostly of large blocks up to several hundred meters across derived from units of the Cutler formation exposed in the vent walls. The interstices between the large blocks are filled with unconsolidated breccia consisting of fragmental debris from the large blocks mixed with limestone fragments from underlying $\mathrm{Pa}$ leozoic formations, crystalline rock fragments from the crust below the Paleozoic section, and some rock and mineral clasts from the upper mantle. Kimberlite is a blackish-green highly serpentinized ultramafic microbreccia constituting about $1 \%$ of the dike. There is no evidence that a silicate melt was ever present at the present erosion surface. All the breccias are particulate and intricately mixed at all scales. Mineral constituents of kimberlite (garnet,

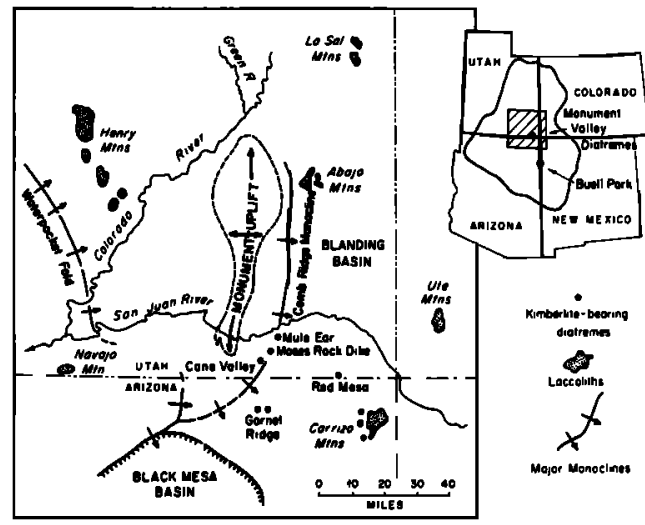

Fig. 1. Map showing the location of the kimberlite-bearing diatremes.

spinel, olivine, pyroxene, phlogopite, serpentine, chlorite, and so forth) can be found dispersed throughout the breccia. Rock fragment populations have size-frequency distributions like those produced by comminution. It is believed that the breccias, including kimberlite, were emplaced at their present levels as a fluidized solid particle and volatile system driven by $\mathrm{CO}_{2}$ and $\mathrm{H}_{2} \mathrm{O}$ [McGetchin, 1968].

The present erosion surface is probably about $1 \mathrm{~km}$ below the ground surface at the time of emplacement of the dike, because clasts derived from overlying formations stratigraphically 1 $\mathrm{km}$ above those presently exposed at the vent walls are found in the Mule Ear diatreme [Shoemaker, 1962].

Fission track dating of apatite in a greenschist fragment from Moses Rock dike yielded an age of $35 \pm 4 \mathrm{~m} . \mathrm{y}$. [Naeser, 1971]; apatites from granitic xenoliths from the Mule Ear diatreme yield apparent ages of $28 \pm 3$ and $30 \pm 3$ m.y. [Naeser, 1971; Naeser and StuartAlexander, 1969].

Analyses of its constituent minerals, kimberlite and related dense-rock fragments from Moses Rock dike, have shed considerable light on the origin of the kimberlite [McGetchin, 1968; McGetchin and Silver, 1968, 1970a]. Mineral grains from kimberlite, in particular pyroxenes and garnets, are compositionally unlike those of most associated xenoliths (eclogite, pyroxenite, serpentinite, gabbroic gneiss, and others) but are similar to those from lherzolite fragments and also to mineral phases occurring as inclusions within pyropic garnets. Pressure 
and temperature assignments were made on coexisting clinopyroxene and garnet and on individual clinopyroxenes (with the assumption that these grains coexisted with garnet or spinel) according to procedures described by $M c G e t c h i n$ and Silver [1970a]. Results indicate that the pyroxenes were derived over a significant depth range in the upper mantle extending from about 50 to about $200 \mathrm{~km}$ and that they come from both spinel- and garnet-bearing peridotite assemblages (Figure 2). Similar minerals collected at Red Mesa, Mule Ear, and the Garnet ridge pipes also indicate that mantle temperatures are modest, probably about $900^{\circ}$ $950^{\circ} \mathrm{C}$, at depths ranging between 50 and 200 $\mathrm{km}$. The data clearly indicated that the kimberlite was derived from disaggregation of $\mathrm{Al}-$ rich and $\mathrm{Al}$-poor pyroxene-bearing peridotite assemblages in the mantle, spinel-lherzolite, and garnet-lherzolite, respectively. The other dense xenolithic rock fragments (eclogite and pyroxenite) are considered to be accidental inclusions derived from the vent walls during the eruption, although they may be volumetrically significant constituents of the mantle. Volatile-bearing minerals including titanoclinohumite, calcite, and amphibole occur as inclusions within pyrope. Clinohumite is intergrown with kimberliteolivine in textural modes precluding its origin as an alteration product; hence it apparently was present in the mantle with minerals derived from both spinel-lherzolite and garnet- lherzolite and is a possible site for volatiles in the upper mantle. The volatile-bearing minerals may have been important in the genesis of kimberlite [McGetchin et al., 1970] and related carbonatite [McGetchin et al., 1973].

\section{Crystalline Rock Fragments in Moses Rock Dike}

Crystalline rock fragments constitute about $3 \%$ of the intrusive material within the Moses Rock dike and as much as $17 \%$ locally. Clasts range in size from silt-sized particles to verywell-rounded boulders up to 2 meters in diameter and show little or no evidence of zonal metamorphism when the surfaces of broken fragments are compared with the center. Approximately $75 \%$ are rocks with igneous or altered igneous textures. Metabasalt, gabbro, and diorite are the most common; rhyolite and granite are less abundant. Approximately $25 \%$ of the fragments are foliated metamorphic rocks. The most abundant metamorphic type is a garnetbearing gabbroic gneiss, probably metagabbro. Acidic metamorphic rocks are present but not abundant. Ultramafic rocks, all with $\rho>3.2$ $\mathrm{g} / \mathrm{cm}^{\mathrm{s}}$, include spinel-bearing lherzolite, eclogite, spinel-bearing websterite, jadeite-pyroxenite, and rare garnet-spinel lherzolite. Together these types form less than $1 \%$ of the total assemblage of crystalline fragments.

The metabasalt is unfoliated and fine grained. Most specimens have experienced greenschist

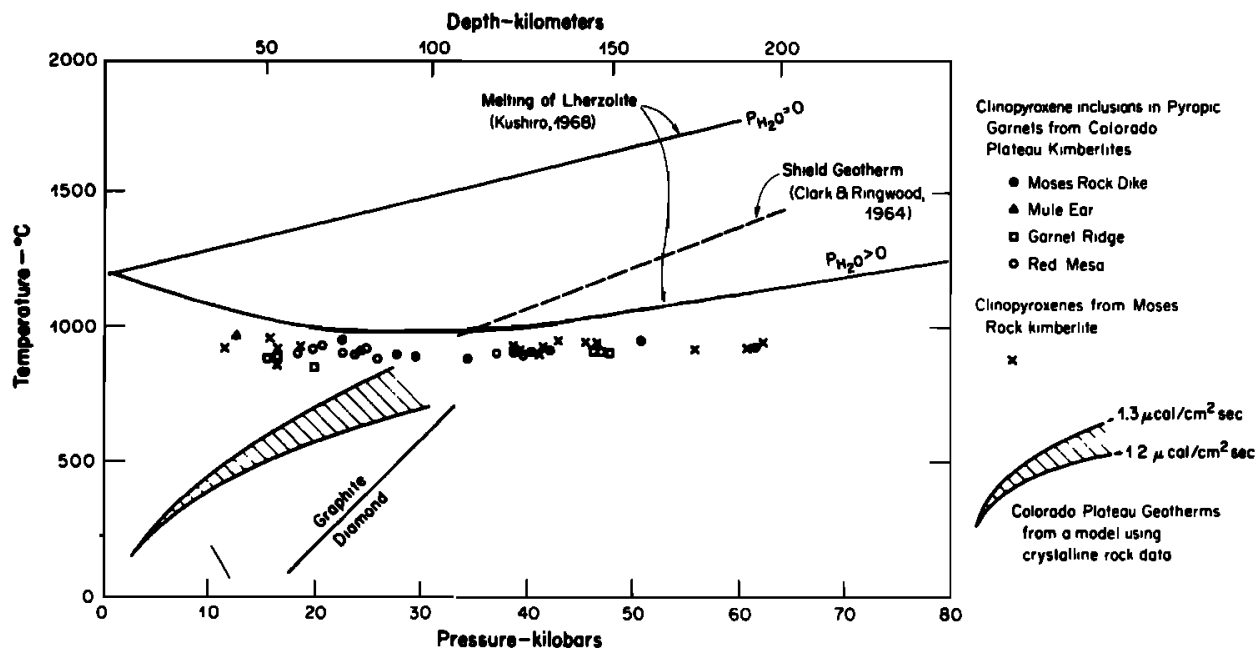

Fig. 2. Estimated conditions of equilibration of clinopyroxene grains from kimberlite and clinopyroxene inclusions in pyrope garnets from Moses Rock dike and related diatremes. 
grade metamorphism with no obvious deformation fabric. White 'phenocrysts' of altered plagioclase (up to $20 \%$ ) occur in forms ranging from small irregular-shaped blobs to $1-\mathrm{cm}$ euhedral pseudomorphs after plagioclase now consisting of epidote and clay minerals. Gabbroic rocks commonly show greenschist grade alteration but no evidence of deformation. Diorite with hornblende and andesine plagioclase is undeformed and generally unaltered. Rhyolite is unaltered and undeformed, and has a microcrystalline groundmass and small $(1 \mathrm{~mm})$ euhedral quartz and alkali-feldspar phenocrysts. Medium- and coarse-grained granitic rocks are present. Medium-grained foliated biotite granite is the most abundant type of acidic rock; porphyritic sphene and biotite-bearing leucogranite and porphyritic quartz monzonite are also present.

The most abundant metamorphic rocks are metagabbroic gneisses consisting of retrograded plagioclase-pyroxene and plagioclase-pyroxenegarnet. These rocks have a relict gabbroic and coarsely layered structure. The pyroxene is generally altered to hornblende, and the plagioclase to epidote, zoisite, sericite, and clay minerals. Garnetiferous felsic gneiss, some with blue quartz, is observed generally with perthitic feldspars and without hydrous phases present. Hornblende-plagioclase 'schist (basic amphibolite) is fairly common, as are highly aluminous schists of amphibolite grade. The aluminous rocks generally have less than $10 \%$ free quartz. Sillimanite-bearing schists are common; andalusite and kyanite were not observed. Calcareous and magnesian assemblages of amphibolite grade also were not observed. The most abundant greenschist grade rocks have basic igneous compositions. Minor calcite was observed in a few low-grade chlorite-rich schists.

Dense crystalline rock fragments observed include eclogite, in which garnet abundance ranges from 1 to $40 \%$ by volume; jadeite-rich pyroxenite with trace rutile $(1 \%)$ and pyrite $(1-2 \%)$; spinel-bearing websterite, a granular-textured rock with aluminous orthopyroxene $\left(6 \% \mathrm{Al}_{2} \mathrm{O}_{3}\right)$ and clinopyroxene $\left(8 \% \quad \mathrm{Al}_{2} \mathrm{O}_{3}\right)$ and large diopsidic megacrysts; partially serpentinized coarsegrained granular-textured spinel-lherzolite; and rare spinel-bearing garnet-lherzolite [Gavasci and Helmstaedt, 1969].

The origin of the dense-rock types is of great interest. The eclogites in the Colorado plateau pipes have already received considerable attention [O'Hara and Mercy, 1966; Watson, 1960, 1967; Watson and Morton, 1969; Helmstaedt and Anderson, 1969; McGetchin, 1968; Banno, 1970; Essene and Ware, 1970; Kumazawa et al., 1971]. Most of these workers agree that at least some of the eclogites are crustal in origin, although the mineral chemistry and the seismic velocities of some of the eclogites, pyroxenites, and peridotites are consistent with a mantle origin. Significant variations in textures and mineral compositions exist within the suite of eclogitic rocks. The crustal or upper-mantle origin of the eclogites is an open question, and we feel that the range of mineral chemistries and textures present may mean that these rocks formed under a range of physical conditions, perhaps in both the crust and the upper mantle.

\section{Relative Size and Abundance of Rock TYPES}

Detailed mapping of breccia in the Moses Rock dike established that clasts derived from sedimentary strata forming the vent walls are distributed such that there is an inverse relationship between block size and distance of transport up the vent from the original position. Hence the deeper the origin, the smaller the size of the fragments. Similar observations have been reported elsewhere by Williams [1936] and Cloos [1941]. If a similar relationship applies to the deep-seated fragments, fragment size would be a clue to the relative depth of origin of the various types of metamorphic and igneous rock fragment (Figure 3).

With this relationship in mind, observations were made of the metamorphic and igneous fragment populations at 28 localities. The variety of rock types present is great, and so size data were gathered on a carefully selected representative suite. At each sample site, rock populations were examined within a bounded area defined on the ground. The largest speciment of each member of the representative suite was located, and previously unrecognized specimen types were collected. The size (maximum dimension) of the largest crystalline fragment at each locality was set equal to 100 , and the size of other fragment types at that locality was expressed proportional to 100 . This number is called the size index. Averaged over all 28 sample localities, the mean size index $N$ is a 


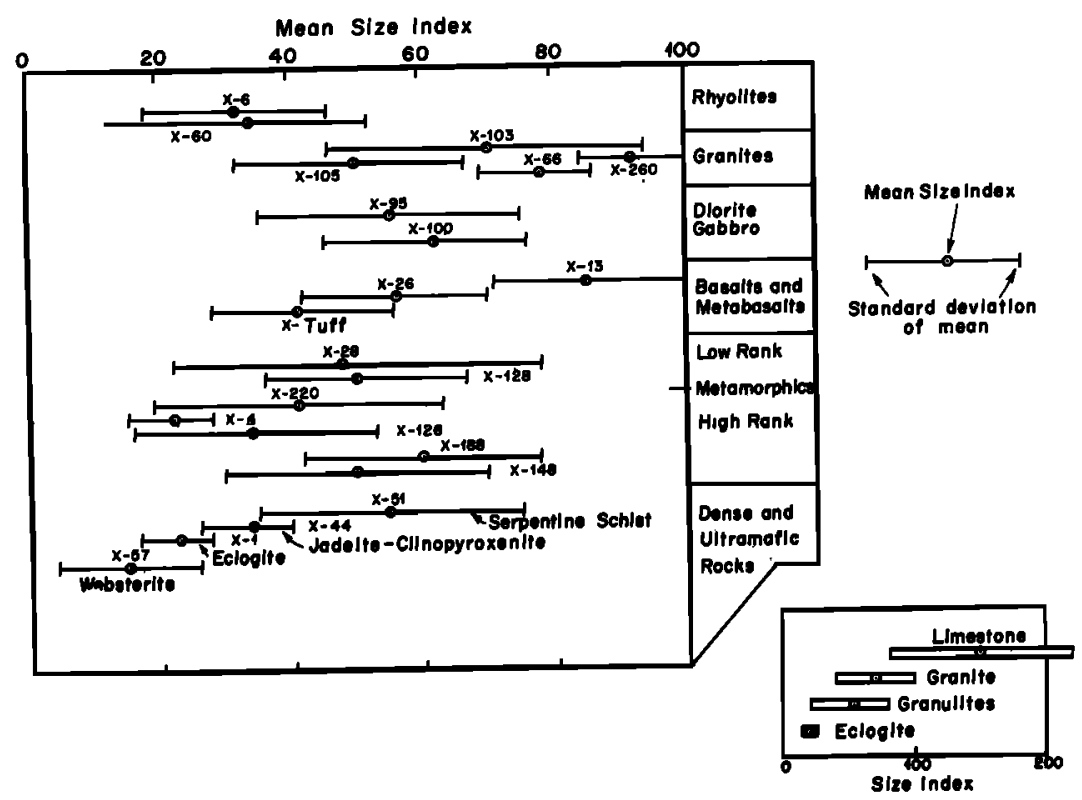

Fig. 3. Relative size of a representative suite of crystalline rock fragment types in the Moses Rock dike on the basis of sampling at 28 localities. Size index is the ratio of the size of a given fragment (largest dimension) to the largest crystalline fragment at the site multiplied by 100; the mean size index is the average over all 28 localities. Bars indicate the standard deviation of the mean. Sample numbers (such as $x$-13) refer to specific rocks described by McGetchin [1968].

measure of the relative size of the various rock types in the representative suite (Figure 3 ).

Mean size indices for the various fragment types fall roughly into three groups (Table 1). A group with a mean size index of $\geq 73$ includes granite and metabasalt. An intermediate group between about 35 and 73 contains some igenous and/or unfoliated metamorphic types (diorite, gabbro, granite and granitic gneiss, and basalt-andesite) and most of the foliated metamorphic types (greenschist, amphibolite, and granulite grade rocks). A third group with size indices of $<28$ contains rhyolite, aluminous schist, and the ultramafic fragments.

If the relative size of the crystalline fragments is, indeed, a simple inverse function of their depth of origin, the mean size index $N$ (Table 1) is an inverse measure of the depth of origin of a given rock type. This relationship would indicate that granite $(N=75)$ and granite gneiss $(N=73)$ originated from shallower depths than gabbro $(N=55)$ and granulite (garnet metagabbro) gneiss $(N=50)$, which in turn originated higher in the section than eclogite $(N=25)$ or websterite $(N=4)$.
The relative abundance of specific xenolith types reflects the influence of many factors, including the relative area exposed in the vent walls, the physical character of the rocks themselves, the nature of the transporting medium, the time changes in the introduction rate, and many others. The relative abundance of fragment types is related to the character and the structure of the rock column traversed by the erupting medium on its way to the surface and particularly to the abundance of rock types in the walls, among other things, such as their relative resistance to comminution.

Sampling aimed at providing relative abundance data on fragments was carried out in three different ways. (1) Visual qualitative estimates were taken at 28 localities by simply visually scanning the ground surface and assigning a relative abundance value. (2) Quantitative collections of fragments were made at five localities at which approximately $200 \mathrm{~kg}$ of material were sampled from just below the surface, screened in the field, bagged and shipped, and weighed and classified in the lab. (3) Quantitative collection of fragments from 
TABLE 1. Summary of Field Data on Crysta1line Rock Fragments Observed in the Moses Rock Dike

\begin{tabular}{lccc}
\hline \multicolumn{1}{c}{$\begin{array}{c}\text { Crystalline } \\
\text { Fragment Type }\end{array}$} & $\begin{array}{c}\text { Mean } \\
\text { Size } \\
\text { Index }\end{array}$ & $\begin{array}{c}\text { Estimated } \\
\text { Relative } \\
\text { Abundance, } \\
\text { wt \% }\end{array}$ & $\begin{array}{c}\text { Measured } \\
\text { Density }\end{array}$ \\
\hline Metabasalt & & & \\
Granite, quartz-monzonite & 85 & 34 & 2.91 \\
Granite gneiss & 75 & 1 & 2.63 \\
Gabbro & 73 & 1 & 2.65 \\
Basalt & 55 & 19 & 2.90 \\
Chlorite schist & 55 & 10 & 2.9 \\
Serpentine schist & 55 & 2 to & \\
Diorite & 55 & 2 to & 2.80 \\
Granulite metagabbro gneiss & 52 & 11 & 3.90 \\
Jadeite-clinopyroxenite & 50 & 17 & 3.34 \\
Rhyolite & 35 & $<1$ & 2.64 \\
Amphibolite & 28 & 1 & 2.99 \\
Eclogite & 27 & 2 & 3.4 \\
Websterite & 25 & $<1$ & 3.26 \\
Spinel-lherzolite & 4 & $<<1$ & 3.3 \\
& & & \\
\hline
\end{tabular}

Rocks listed in order of decreasing mean size index.

the ground surface at the same five localities was made by using a 200-point rectangular grid in which the grid intersection points were separated by $30 \mathrm{~cm}$. The results (Table 1) are based on the five bulk subsurface samples (method 2); results from the other methods were very similar [McGetchin, 1968].

Metabasalt is the most abundant rock type. Gabbro and garnetiferous metagabbroic (granulite) gneisses are also abundant; basalt and diorite are common. Rocks of low metamorphic grade and granite are less common. Least abundant are the eclogite, pyroxenite, and peridotite types.

To summarize, the principal observations and inferences relevant to all attempts to reconstruct the column are as follows. (1) Metabasalts and granite are abundant and are the largest fragment types; therefore they are inferred to be abundant in the upper part of the crust. (2) Gabbro and diorite fragments are moderately large and have suffered no more than modest retrograde metamorphism; hence they are young or shallow or perhaps both. (3) In general, low- rank metamorphic rocks are larger than highrank metamorphic types; basic metamorphic compositions are more abundant than more acidic (or pelitic) types. Sillimanite was observed but not kyanite or andalusite; many of the metamorphic rocks show the effect of retrograde metamorphism. We feel that these rocks constitute a pile of metavolcanic and metaplutonic rocks (mainly basalts and gabbros) increasing in metamorphic grade with depth from greenschist facies assemblages near the surface, amphibolite grade rocks at intermediate depths, and granulite grade rocks (garnetiferous metagabbro) at depth. Also, we feel that these rocks probably grade downward more or less continuously to plagioclase-bearing eclogitic rocks, eclogites, and pyroxenites (4) The serpentine schist is abundant and is interesting because it could be stable within the uppermost mantle, given a sufficiently low geothermal gradient. Its seismic properties are probably very similar to those of the garnetiferous gabbro gneiss. (5) The upper mantle from which the kimberlite was derived is believed to consist of spinel-lherzolite 
that undergoes a phase transition with increasing depth to garnet-lherzolite [McGetchin and Silver, 1970a]. The other ultramafic fragment types (eclogite, websterite, jadeite-clinopyroxenite, and serpentine schist) are believed to be accidental inclusions (i.e., fragments of the vent walls). These fragments, however, might originate in either the upper mantle or the lower crust. (6) The rhyolite clasts clearly do not fit the neat inverse size-depth scheme described above. They occur as small, commonly very angular fragments. Their small size would suggest a deep origin, yet they are unaltered, have experienced no apparent retrograde metamorphism, and would most reasonably constitute a part of a relatively young and shallow volcanic terrain. (Preliminary uranium-lead isotopic dates suggest that these rocks are of Precambrian age, about $1700 \mathrm{~m} . \mathrm{y}$.). It is felt that the rhyolites, indeed, have shallow origins and that their anomalously small size is due to their pervasively fractured habit in situ, which would result in intense fragmentation during transport. Such a view is consistent with their typically angular shapes in comparison with other fragment types and is also consistent with typical field occurrence of rhyolites, such as that in the Precambrian of southern Arizona.

After the available geophysical and drill core data are reviewed, these considerations will be integrated into a model for the distribution of rock types with depth.

\section{Regional Geophysics and Drill Core Data}

A great deal is known about the local subsurface structure, which bears directly on the composition of the crust and upper mantle underlying the Moses Rock dike. A reversed seismic refraction profile has been recorded betwcen Hanksville, Utah, and Chinle, Arizona, through Monument Valley very near the Moses liock dike. The variations of $P$ wave velocity with depth in the vicinity of the dike were interpreted by Roller [1965] to be $3 \mathrm{~km} / \mathrm{sec}$ from the surface to $3 \mathrm{~km}, 6.2 \mathrm{~km} / \mathrm{sec}$ from 3 to $28 \mathrm{~km}$, and $6.8 \mathrm{~km} / \mathrm{sec}$ from 28 to $43 \mathrm{~km}$, with the $M$ discontinuty at $43 \mathrm{~km}$ and an uppermantle $P$ velocity of $7.8 \mathrm{~km} / \mathrm{sec}$. Julian [1970] presented a model for deeper parts of the upper mantle of the Colorado plateau with velocities of $7.8 \mathrm{~km} / \mathrm{scc}$ from 43 to $100 \mathrm{~km}$ and $8.2 \mathrm{~km} / \mathrm{sec}$ from 100 to about $115 \mathrm{~km}$; in a low-velocity channel extending to about $160 \mathrm{~km}, P$ velocity was about $7.7 \mathrm{~km} / \mathrm{sec}$. The bottom of the lowvelocity zone, of course, is only poorly defined, but a gradual increase in $P$ velocity between $8.2 \mathrm{~km} / \mathrm{sec}$ at a depth of $160 \mathrm{~km}$ and $8.5 \mathrm{~km} / \mathrm{sec}$ at a depth of about $360 \mathrm{~km}$ is suggested. The upper mantle in the western United States is characterized by a low $P$ wave velocity (7.8 $\mathrm{km} / \mathrm{sec})$ and a low rock density $\left(3.3 \mathrm{~g} / \mathrm{cm}^{3}\right)$ [Pakiser and Zietz, 1965].

Aeromagnetic and gravity surveys reveal regional NE-SW trends believed to reflect buried regional features in the crystalline rocks of the crust [Case and Joesting, 1961]. Although crystalline basement rocks do not crop out in the vicinity of the Moses Rock dike, they are exposed in the region in the San Juan Mountains and on the Uncompaghre uplift in southwest Colorado, on the Defiance uplift in New Mexico, and in the inner gorge of the Grand Canyon in Arizona. Rocks exposed are igneous and amphibolite grade metamorphics, in general. Foliated rocks generally trend $\mathrm{NE}$, parallel to the regional magnetic and gravity trends. These trends are of considerable interest in the context of the seismic results cited above because the refraction profile of Roller [1965] crossed the regional grain nearly orthogonally; Julian's [1970] results were based on data from a long, nearly E-W profile running nearly parallel to the grain. If the crust and upper mantle are grossly foliated parallel to the magnetic and gravity trends, an azimuthal dependence of seismic velocity might be anticipated, the grentest velocity being parallel to the foliation (i.e., in the SW-NE direction). Low values of velocity anisotropy in individual hand specimens, such as those observed in eclogite from the Mule Ear diatreme [Kumazawa et al, 1971], however, need not preclude such regional anisotropy, because regional inhomogeneities may result from largescalc banding. Both Roller and Julian report an upper-mantle $P$ wave velocity of $7.8 \mathrm{~km} / \mathrm{sec}$. A high-resolution experiment consisting of orthogonal (NW and NE) refraction profiles centered in the Colorado plateau would be of real interest in determining whether the crustal NE-SW structural grain extends into the upper mantle.

Porath [1971] described electrical conductivity models for the Colorado platean and adjacent regions on the basis of a large magnetometer array. Results suggest that the upper- 
most mantle of the Colorado platenu has an electrical conductivity lower than that of the adjacent Basin and Range and Rocky Mountain provinces but somewhat higher than that of the mid-continental United States. He suggests that the higher conductivities observed in the Basin and Range and Rocky Mountain provinces are consistent with higher temperatures, phase transitions, and compositional changes or partial melting or both. Consequently, heat flow data are of great interest.

Unfortunately, heat flow data are sparse. Roy [1963] has measured two relatively high values in Utah, both in mining districts that probably are not typical of the region. More recent measurements suggest that regional heat flow is near or only slightly above normal, probably in the range 1.2-1.5 [Roy et al., 1968; Sass et al., $1971]$.

Some crystalline basement rocks have been obtained from drill holes in the region. In southwestern Colorado, about $100 \mathrm{~km}$ east of Moses Rock, Edwards [1966] described orthogneiss, granitized paragneiss, granitic igneous rocks, and calcareous and quartzo-feldspathic pelitic and basic paragneiss, the NE-trending foliation paralleling the regional trends. Drill holes near Bluff, Utah, about $30 \mathrm{~km}$ east of Moses Rock, produced granite and quartzite [Fitzsimmons, 1963, p. 14]. Fitzsimmons also reports that chlorite schist or phyllite consisting of chlorite and quartz was encountered at Bluff. Thus the literature suggests that the uppermost basement consists of granitic rocks mixed with basic metavolcanics and metasediments(?) of amphibolite and greenschist metamorphic grade. The crystalline fragments in the Moses Rock dike include these types and many others not observed in drill cores. Undoubtedly, this greater variety of rock types reflects sampling by the erupting kimberlite through a vastly greater vertical extent.

\section{Model for Colorado Plateau Crust and UPPER Mantle}

Our model for the volumetric distribution of rocks with depth beneath the Colorado plateau (called CP-1) is summarized in Figure 4. It is based fundamentally on the size and the relative abundance of the crystalline fragments (Table 1) but is believed to be consistent with available petrologic and geophysical data.

The distribution of crustal rocks in the model suggests that the upper part of the crust is granite, gneissic granite, metabasalt, diorite, and gabbro. These rocks are either unaltered or have been subjected to greenschist grade metamorphism only. In this model the middle and lower crusts consist of amphibolite and granulite grade metamorphic rocks, mostly high-rank metagabbroic gneisses, all of which bear the imprint of retrograde metamorphism to greenschist or

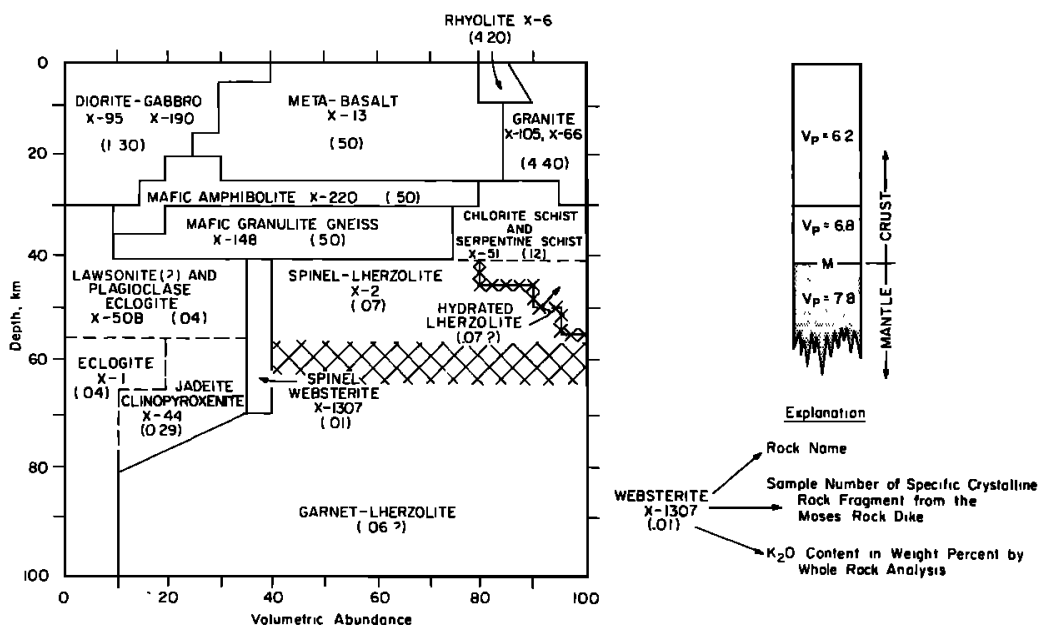

Fig. 4. Estimated volumetric abundance of rocks constituting the crust and upper mantle under the Moses Rock dike. Sample numbers (such as MRX-13) refer to specific rocks described by McGetchin [1968]. 
amphibolite grade. Eclogite, chlorite schist, serpentine schist, and pyroxenite may occur in this high-rank terrain in the lower crust.

The $M$ discontinuity occurs near a depth of $43 \mathrm{~km}$, a region that may be petrologically complex. The M discontinuity may represent (1) a phase transition from garnet-gabbro gneiss (mafic granulite gneiss of Figure 4) to eclogite, (2) a chemical compositional boundary separating gabbroic gneiss in the lower crust from partially hydrated spinel-lherzolite in the upper mantle, or (3) a hydration boundary separating serpentine schist of the lower crust from only partially hydrated $(\sim 20 \%)$ spinel-lherzolite below. We believe a plausible model for the $M$ discontinuity involves all three transitions as shown in Figure 4, in which a lower crust composed mainly of garnet-bearing gabbroic gneisses mixed with subordinate amounts of eclogite and serpentinite gives way to an upper mantle of partially hydrated spinel-lherzolite containing lenses and pods of eclogite and pyroxenite (spinel-websterite and jadeite-clinopyroxene). Mineral data suggest that the upper mantle is phase layered, spinel-peridotite passing downward to garnet-peridotite with increasing depth [McGetchin and Silver, 1970a].

Some of the eclogite, the websterite, and the clinopyroxene may have originated as basaltic partial melting products of the mantle peridotites that crystallized in the upper mantle. The same melts, if they were propagated higher into the upper crust, crystallized as basalt, gabbro, or diorite. The garnetiferous gabbro resulted from crystallization in the lower crust. Such origins are consistent with the igneous and metaigneous textures of most of the xenoliths and with their whole-rock chemistry.

We believe that the crust underlying the Colorado plateau evolved predominantly by igncous processes rather than by scdimentary ones.

\section{Chemical Composition of Colorado Plateau Crust, Upper Mantle, and Lithosphere}

The model shown in Figure 4 suggests that the crust $(0-40 \mathrm{~km}$ in depth) consists of the following rock types: $11 \%$ acidic plutonic and volcinic rocks; $20 \%$ plutonic rocks of intermediate composition; about $66 \%$ metamorphic rocks of basic composition and metaigneous origin; and $2-3 \%$ eclogite. The upper mantle
(40-100 $\mathrm{km}$ in depth) is about $25 \%$ eclogite, $2-3 \%$ aluminous pyroxene pyroxenite, and $73 \%$ peridotite (about one-fifth spinel-lherzolite and four-fifths garnet-lherzolite).

By using the avalable chemical analyses on the rocks shown in Figure 4 (data from $\mathrm{Mc}$ Getchin [1968]; McGetchin and Silver [1970a]; and subsequent unpublished analyses from the U.S. Geological Survey (USGS) on 11 specimens), the bulk chemical compositions of the crust $(0-40 \mathrm{~km})$, the upper mantle $(40-100$ $\mathrm{km})$, and the lithosphere $(0-120 \mathrm{~km})$ were calculated. These results are shown in Table 2, together with selected items drawn from the literature for comparison. Whole-rock analyses on all the important rocks except garnetlherzolite are available, and the calculations were made by using the volumetric abundances shown in Figure 4. The composition of the garnet-lherzolite was assumed to be that of anhydrous Moses Rock kimberlite (see $\mathrm{Mc}$ Getchin and Silver [1970a, Table 1, analysis 13] and the accompanying text in which a detailed argument is presented showing that Moses Rock kimberlite is physically disaggregated uppermantle peridotite, which is mainly garnet-peridotite with little or no contamination by crustal or eclogitic material).

The calculated composition of the anhydrous Colorado plateau crust (Table 2, column 2) is considerably more basic $\left(54 \% \quad \mathrm{SiO}_{2}\right)$ than estimates of the crustal compositions of shield areas $(60-66 \%)$ or the western United States regionally $(60 \%)$, and it is particularly more magnesian than the compositions of these models. The Colorado-plateau crustal model falls approximately halfway between average oceanic tholeiite and average island arc andesite in most oxides, except that it is slightly more magnesian and less aluminous.

The calculated composition of the Colorado plateau upper mantle from 40 to $100 \mathrm{~km}$ in depth (Table 2, column 9) is slightly less basic $\left(\begin{array}{lll}48 \% & \mathrm{SiO}_{2}\end{array}\right)$ than the compositions of most mantle models, which range from 45 to $48 \%$, generally. It is more aluminous, more sodic, and less magnesian than pyrolite models or most garnet-peridotite xenoliths. Although it is in fairly good general agreement with Mason's [1966] model (Table 2, column 12), it is depleted in iron. Press [1968] and others have argued that the upper mantle has a higher 
Colorado Plateau Crustal-Upper-Mantle Model

7031

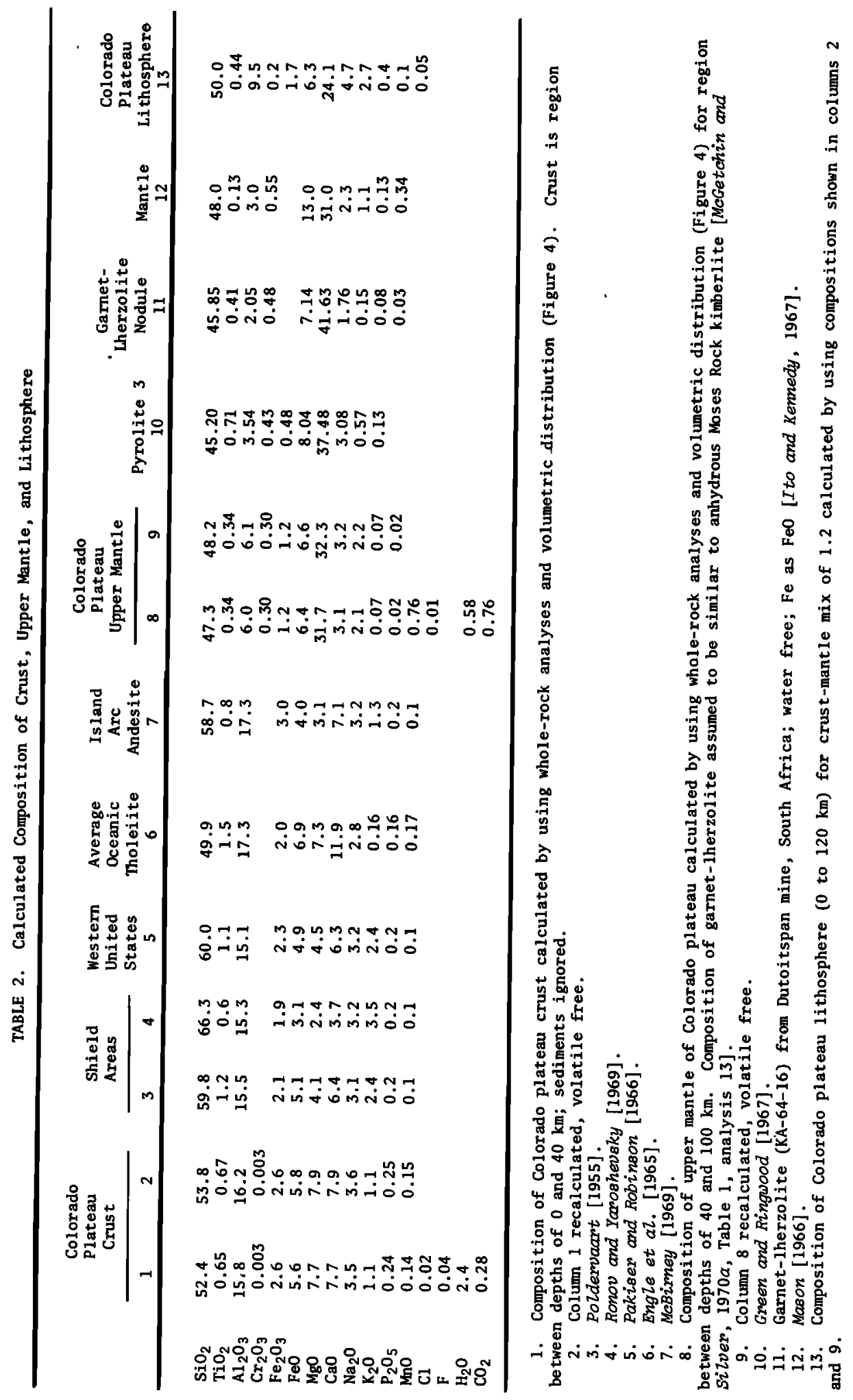


density and higher seismic velocities than pyrolite and garnet-peridotite models permit and that it requires admixture of a significant amount of eclogite. This model for the upper mantle of the Colorado plateau is about onefourth eclogite. The high $\mathrm{SiO}_{2}$, alumina, and soda contents relative to pyrolite imply more jadeite and garnet; both garnet and jadeite are high-density high-velocity phases.

The Colorado plateau crust is silica poor rela(ive to estimates of crustal composition elsewhere; the upper mantle, however, is silica rich. One is tempted to speculate that the Colorado plateau lithosphere may be less differentiated than that of most regions, a view that might be consistent with its relative tectonic stability. On the other hand, this chemical conclusion could be an artifact of error in the model. There are three prominent possible sources of error.

1. Because coarse-grained granitic rocks are preferentially eroded in the field, their relative abundances might be underestimated.

2. The possible crustal origin of some or much of the eclogite would make the mantle more ultrabasic in composition and more like pyrolite or peridotite models.

3. Erupting kimberlite may sample rocks from the vent walls in nonrandom ways such that even large and carefully designed surface samples are not representative of a vertical cross section.

The first problem may yield to more field work and similar studies at other vents, the second to detailed mineralogy and petrology, and the third perhaps only to deep drilling into the continents.

Finally, Julian [1970] inferred the top of the Colorado plateau low-velocity zone to be at a depth of about $115 \mathrm{~km}$. Thus, if we assume the lithosphere to be of the order of $120 \mathrm{~km}$ thick, its composition will be approximately a $1: 2$ mix of the crust and upper mantle, respectively. The result of such a mix is shown in column 13 of Table 2.

\section{Physical Properties}

The physical properties of the model can be explored by averaging the propertics of each layer in the appropriate way.

The density of a mixture of the fragment types is proportional to their relative volumes. Rock densities have been measured on all the abundant rock types. When the effects of compressibility and thermal expansion are neglected, the resulting density profile for the upper 100 $\mathrm{km}$ varies between $2.80 \mathrm{~g} / \mathrm{cm}^{3}$ near the surface to $2.93 \mathrm{~g} / \mathrm{cm}^{\prime \prime}$ just above the $\mathrm{M}$ discontinuity, increases to $3.24 \mathrm{~g} / \mathrm{cm}^{3}$ just below the $\mathrm{M}$ discontinuity, and reaches $3.4 \mathrm{~g} / \mathrm{cm}^{3}$ at $80 \mathrm{~km}$ (Figure $5 a$ ) .

Seismic wave propagation velocities or elastic properties have been measured on a few sclected specimens, but, for most of the rocks, estimates of $P$ wave velocities were made from Press's tabulation (presented by Clark [1966]), which is based largely on Birch's [1960, 1961] experimental data. Because few detailed petrographic data are included in these tabulations, the velocity estimates are tenuous. A very rough temperature correction, which amounted to about $0.1 \mathrm{~km} / \mathrm{sec}$ at $1000^{\circ} \mathrm{C}$ (near $10 \mathrm{~kb}$ ), was applied graphically. Although the wave propagation velocities of heterogeneous mixtures such as gneissic or foliated rocks depend on the geometry of the mixture, a simple harmonic average was applied, where

$$
V_{P}=\sum_{i}\left(\frac{x}{v_{p}}\right)_{i}^{-1}
$$

where $x$ is the volume fraction and $v_{p}$ is the compressional velocity of each component rock. The result for our model can be compared with the seismic velocity with depth inferred by Roller [1965] (Figure 5b). The coincidence of the locations of the seismic discontinuities is insignificant because the seismic data were used in establishing the boundaries of the petrologic model. It is of interest, however, to compare the predicted velocities at various depths with observations. The upper-crust velocities are higher than those observed by Roller by about $0.3-0.4$ $\mathrm{km} / \mathrm{sec}$, and the lower crustal velocities are higher by about $0.3 \mathrm{~km} / \mathrm{sec}$. This may mean that the abundance of low-density (generally acidic) rocks may be underestimated in the model. The upper-mantle velocities are in reasonably good agreement near the $\mathrm{M}$ disconinuity.

Temperature estimates are of particular interest. Calculations of the steady-state temperature distribution within the earth are common in the literature. Perhaps the most well-known recent treatment of the problem (and the most commonly cited) is that of Clark and Ringwood 
[1964] (dashed lines in Figure 5d). Because chemical analyses were available on most of the important xenolith types [McGetchin, 1968], the $\mathrm{K}_{2} \mathrm{O}$ content as a function of depth could be calculated for the model. The $\mathrm{K}_{2} \mathrm{O}$ contents of the spinel-peridotite and the garnetperidotite were assumed, not measured, by using analyses of two Moses Rock kimberlite samples [McGetchin and Silver, 1970a]. These upper bounds on the $\mathrm{K}_{2} \mathrm{O}$ content of the mantle may be reasonable. Because $\mathrm{U}$ and $\mathrm{Th}$ concentrations were not determined in any specimens, some estimate of their abundance was required to calculate the total heat production rate. Wasserburg et al. [1964] concluded that the best estumates of the ratios of $\mathbf{K}, \mathbf{U}$, and $T h$ for the outer parts of the earth are $\mathrm{K} / \mathrm{U}=10^{4}$ and $\mathrm{Th} / \mathrm{U}=3.7$. Considerable controversy exists over these values, however, because of the spread observed in possible mantle-derived rocks [Wakita et al., 1967; Green et al., 1968]. By using the ratios of Wasserburg et al. and the energies given by Wetherill (presented by Clark [1966]), for the decay of K, U, and Th, the total radioactive heat production rate with depth was calculated. It is similar to but somewhat greater than that assumed by Clark and Ringwood [1964] for continental areas and considerably more radioactive than their shield model (Figure $5 d$ ). The thermal conductivites of silicate rocks are not precisely known, especially at elevated temperatures. No determinations of thermal conductivity have been made on the specimens from Moses Rock dike. In these calculations a temperature-dependent conductivity was used following the method of Clark and Ringwood [1964], who note that hydrous phases greatly reduce the IR transparency of silicate rocks owing to the resonance excited in the $\mathrm{O}-\mathrm{H}$ bonds at IR frequencies. Because serpentine-, amphibole-, and chloritebearing rocks are inferred to be abundant in the lower crust and other hydrous minerals are inferred to be abundant in the uppermost mantle, the thermal conductivities assumed might be too low.

By using Clark and Ringwood's [1964] estimate of thermal conductivity and the radioactive heat production rates described above, steady-state geotherms for assumed surface fluxes of 1.2 and $1.4 \mathrm{cal} / \mathrm{cm}^{2} \mathrm{sec}$ were calculated. The results (Figure 5e) are as follows. (1)

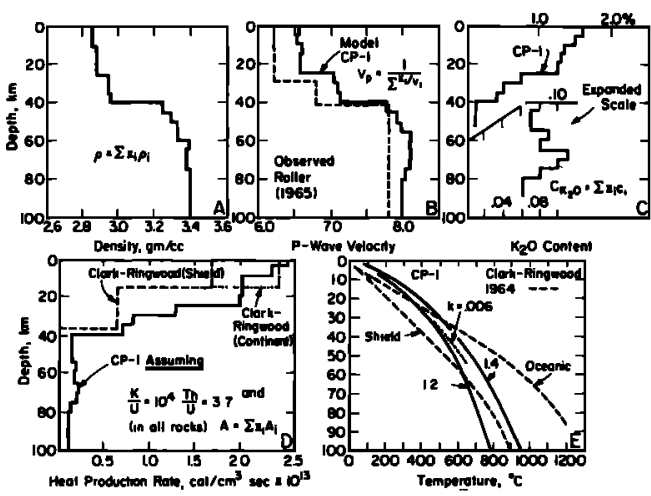

Fig. 5. Some calculated physical properties of the crustal-upper-mantle model.

There is more curvature than there is in Clark and Ringwood's [1964] results owing to the relatively higher radioactivity of the model. (2) Temperatures at depth are in general agreement with the inferred conditions of crystallization of the kimberlite clinopyroxenes. Agreement is best at depths of $100-200 \mathrm{~km}$. Shallower depths deviate from this steady-state curve (see Figure 2). (3) Hydrous rocks are probably present or even abundant in the lower crust and upper mantle. When a thermal conductivity of $0.006 \mathrm{cgs}$ (equivalent to hydrous rocks) is assumed, calculated geotherms are deflected to somewhat higher temperatures (dotted line in Figure $5 e$ ). The effect of abundant serpentine near the $M$ discontinuity probably would not displace the geotherm at greater depth by more than about $100^{\circ} \mathrm{C}$ upward, however.

These calculated geotherms can be compared with some experimentally determined phase boundaries of interest. The calculated geotherms cross the boundary between garnet-peridotite and spinel-peridotite between about 14 and 16 kb (about $42-48 \mathrm{~km}$ ), according to the experimental results of Boyd and MacGregor [1964] and Green and Ringwood [1967]. The results of Ito and Kennedy [1967] suggest that spinelperidotite might not be stable along this envelope of geotherms at all, although MacGregor [1970] has shown that the stability field of spinel-lherzolite is expanded by the presence of chrome and ferric iron. The stability field of serpentine is intersected between 12 and $15 \mathrm{~kb}$, according to the experimental results of Kitahara et al. [1966]. If the mantle is wet, ser- 
pentine may be stable at depths shallower than about $45 \mathrm{~km}$, and it is thus suggested that the layer between 30 and $42 \mathrm{~km}$ could be heavily serpentinized peridotites. The abundant antigorite-tremolite schist fragments and hydrated spinel-lherzolite could originate here. Observed spinel-lherzolite xenoliths are commonly partially serpentinized. Modal analysis of one specimen indicated that it was $18 \%$ serpentine, a typical value. By using Christensen's [1966] results, the $P$ wave velocity of this spinel-lherzolite, approximately $\left(\mathrm{ol}_{40} \mathrm{px}_{40} \operatorname{ser}_{20}\right)$, would be about $7.5 \mathrm{~km} / \mathrm{sec}$ uncorrected for temperature. Thus a slightly more serpentinized spinellherzolite (30\% serpentine content) would have a $P$ wave velocity of $6.8 \mathrm{~km} / \mathrm{sec}$, quite like that of the $30-$ to $42-\mathrm{km}$ layer under the Moses Rock dike.

\section{Discussion}

It is clear that the history of the crystalline rock fragments is complex and involves volcanism, plutonism, a granulite grade metamorphism, and a retrograde metamorphism, all occurring prior to inclusion and transport to the surface in the erupting kimberlite. The episodes recorded in these rocks (in textures, mineral assemblages, and mineral and isotopic chemistry) carry the imprint of the processes that were active deep in the crust and upper mantle and that ultimately were responsible for shaping the surface of the Colorado plateau. It is of great interest to know when the crustal rocks acquired their present configuration and character and how the time sequence of metamorphic events recorded in the rocks from intermediate and great depths relate to igneous rocks now exposed at the surface, possible mantle rocks, and other important regional tectonic events.

If the lithosphere underlying the Colorado plateau is detached at the low-velocity zone from the deeper mantle in the depth range $120-160 \mathrm{~km}$ and is moving relative to the underlying upper mantle, it is conceivable that the location in the mantle from which the kimberlite erupted could be removed horizontally from the present surface position of the diatremes by as much as $600 \mathrm{~km}$, if a relative motion of 2 $\mathrm{cm} / \mathrm{yr}$ and an age of $30 \mathrm{~m} . \mathrm{y}$. are assumed.

On a global scale the zone in the upper mantle between depths of 100 and $200 \mathrm{~km}$ is of particular interest because it contains the low-velocity zone, because magmas are generated in it, and because continents perhaps slide on it. In the Colorado plateau this zone has the following properties.

1. It has low $Q$ [Solomon, 1972].

2. It has low seismic velocities [Roller, 1965; Pakiser and Zietz, 1965; Julian, 1970].

3. It has low electrical conductivity [Porath, 1971].

4. It was the source region for some kimberlite minerals and contained garnet-peridotite at apparently subsolidus temperatures (about $\left.950^{\circ} \mathrm{C}\right)$ [McGetchin and Silver, 1970a].

5. It contains volatile-bearing minerals, including titanoclinohumite [McGetchin et al., [1970], and also amphibole and carbonate (T. R. McGetchin, unpublished data, 1972; McGetchin et al. [1973]).

6. It probably contained the reservoir from which kimberlite, carbonatite, and minette diatremes were emplaced by a violent mode of eruption that apparently required a large supply of volatiles.

We feel that all these observations are consistent with a view that the upper mantle of the Colorado plateau may contain (or contained) significant interstitial volatile-rich fluid phases at temperatures below the silicate solidus.

\section{SUMMARY}

Field data on the relative size and abundance of rocks occurring as xenoliths in Moses Rock dike provide a means of constructing models for their distribution and abundance in the crust and upper mantle.

The total depth of the column sampled by the erupting kimberlite is estimated to be at least $200 \mathrm{~km}$ on the basis of the composition of mineral phases in kimberlite [McGetchin and Silver, 1970a].

In the model for volumetric distribution of rocks in the crust and upper mantle, the crust consists of granite, rhyolite, and metabasalt near the surface but grades downward to basic metaigneous rocks (garnetiferous gabbroic gneiss) in the lower crust with possible serpentinite. The bulk crust chemically is more basic than that in most other crustal models. Crustal rocks are predominantly igneous and metaigneous, and the crust is believed to have evolved primarily by igneous processes.

The upper mantle is believed to be a mix of 
subordinate amounts of eclogite (perhaps onefourth) with minor aluminous pyroxene pyroxenite and peridotite (mainly garnet-peridotite with minor spinel-lherzolite). Inferred uppermantle temperatures permit serpentinite and low-temperature eclogite in the uppermost mantle. The calculated chemical composition of the upper mantle of the Colorado plateau is rich in silica, alumina, and soda relative to the pyrolite models or the garnet-lherzolite nodules.

The observed rock fragments in the Moses Rock dike suggest that the $\mathbf{M}$ discontinuity may involve not one but three types of transitions: (1) phase change from garnetiferous gabbroic gneiss to eclogite, (2) hydration relations involving spinel-peridotite and serpentinite, and (3) chemical transition from gabbroic crustal rocks to peridotites and pyroxenites, the depth reflecting mainly change in silica and magnesia.

The following items are consistent with the view that the region between depths of 100 and $200 \mathrm{~km}$ beneath the Colorado plateau is (or was) volatile rich and at subsolidus temperatures.

1. Low $Q$.

2. Low $P$ and $S$ velocities.

3. Low bulk density.

4. Low electrical conductivity.

5. Source region for kimberlite minerals indicating subsolidus temperatures $\left(\sim 950^{\circ}-\right.$ $1000^{\circ}$ ) (see Figure 2).

6. Low calculated temperatures (e.g., $550^{\circ} \mathrm{C}$ at the $\mathrm{M}$ discontinuity, $42 \mathrm{~km}$ ) (see Figures 2 and 4).

7. The fact that volatile-bearing minerals, including titanoclinohumite, amphibole, and carbonate, were derived from this zone.

8. The fact that it was the source region of intrusive rocks (kimberlite, carbonatite, and lamprophyre) requiring volatile-charged eruptions to produce the observed intensive brecciation, fragmentation, and particle transport.

We suggest that subsolidus fluids and volatiles (water, $\mathrm{CO}_{2}$, and carbonate) may be important in creating the low-velocity zone, particularly in stable platform areas, and are crucial in the tectonics of the platforms.

Acknowledgments. We are grateful for reviews by E. Wolfe and D. Stuart-Alexander of the U.S. Geological Survey, and Herwart Helmstaedt of McGill University, and for helpful discussions with many colleagues. In particular, we thank
E. M. Shoemaker for advice, stimulation, and support over many years.

This report summarizes research carried on from 1965 to the present. It was supported by the National Aeronautics and Space Administration through grants to M.I.T. (NGR-22-009-637) and to the U.S. Geological Survey's Center for Astrogeology (R-66), by the Geological Society of America (Penrose grant 1040-65), by the Atomic Energy Commission under contract to the California Institute of Technology (AT (04-3)-767, CALT-767P7-61). by the U.S. Air Force (under faculty research project AFIT-68-14, Air Force Institute of Technology and AFIT-OAR contract F-33601-69-C-0568), and by the National Science Foundation (GA-31728).

The senior author held a NASA graduate traineeship at Cal Tech from 1965 to 1967 at the inception of the project; from 1967 to 1969 , he was an active duty captain in the U.S. Air Force assigned as assistant professor in the School of Engineering, AFIT, Wright-Patterson Air Force Base, Ohio; he is currently assistant professor, Department of Earth and Planetary Sciences, M.I.T.

\section{REFERENCES}

Banno, S., Classification of eclogites in terms of physical conditions of their origin, Phys. Earth Planet. Interiors, 3, 405-421, 1970.

Birch, F., The velocity of compressional waves in rocks to 10 kilobars, 1, J. Geophys. Res., 65, 1083-1102, 1960.

Birch, F., The velocity of compressional waves in rocks to 10 kilobars, 2, J. Geophys. Res., 66, 2199-2224, 1961.

Boyd, F. R., and I. D. MacGregor, Ultramafic rocks, Carnegie Inst. Washington Yearb., 69, 152-156, 1964.

Case, J. W., and H. R. Joesting, Precambrian structures in the Blanding basin and Monument upwarp, southeast Utah, U.S. Geol. Surv. Prof. Pap., 424-D, 287-291, 1961.

Christensen, N. I., Elasticity of ultrabasic rocks, J. Geophys. Res., 71, 5921-5931, 1966.

Clark, S. P. (Ed.), Handbook of Physical Constants, Mem. 97, pp. 195-218, Geological Society of America, Boulder, Colo., 1966.

Clark, S. P., and A. E. Ringwood, Density, distribution, and constitution of the mantle, Rev. Geophys. Space Phys., 2, 35-88, 1964.

Cloos, H., Bau und Tatigkeit von Tuffschloten, Geol. Rundsch., 32, 705-800, 1941.

Davidson, C. F., On diamondiferous diatremes, Econ. Geol., 59, 1368-1380, 1964.

Dawson, J. B., Basutoland kimberlites, Bull. Geol. Soc. Amer., 78, 545-560, 1962.

Edwards, J., Jr., The petrology and structure of the buried Precambrian basement of Colorado, Quart. Colo. Sch. Mines, 61, 436 pp., 1966.

Engle, A. E. J., C. G. Engle, and R. G. Haven, Chemical characteristics of oceanic basalts and 
the upper mantle, Geol. Soc. Amer. Bull., 76, 711-734, 1965.

Essene, E., and N. G. Ware, The low temperature xenolithic origin of eclogites in diatremes, NE Arizona, Geol. Soc. Amer. Abstr. Prog., 547, 1970.

Fitzsimmons, J. P., Precambrian of the Four Corners area, in Shelf Carbonates of the Paradox Basin, Four Corners Geol. Soc. Guideb., edited by P. O. Bass, pp. 13-20, Four Corners Geological Society, 1963.

Forbes, R., and H. Kuno, Peridotite inclusions and basaltic host rocks, in Ultramafic and Related Rocks, edited by P. J. Wyllie, pp. 328337, John Wiley, New York, 1967.

Gavasci, A. T., and H. Helmstaedt, Pyroxenerich garnet peridotite inclusion in an ultramafic breccia dike at Moses Rock, southeast Utah, $J$. Geophys. Res., 74, 6691-6695, 1969.

Green, D. H., and A. E. Ringwood, The stability fields of aluminous pyroxene peridotite and garnet peridotite and their relevance in upper mantle structure, Earth Planet. Sci. Lett., 3, 151-160, 1967.

Green, D. H., J. W. Morgan, and K. S. Heier, Thorium, uranium and potassium abundances in peridotite inclusions and their host basalts, Earth Planet. Sci. Lett., 4, 155-166, 1968.

Helmstaedt, H., and O. L. Anderson, Petrofabrics of mafic and ultramafic inclusions from kimberlite pipes in southeastern Utah and northeastern Arizona (abstract), Eos Trans. $A G U, 50,345$, 1969.

Ito, K., and G. C. Kennedy, Melting and phase relations in a natural peridotite to 40 kilobars, Amer. J. Sci., 265, 519-538, 1967.

Jackson, E. D., The character of the lower crust and upper mantle beneath the Hawaiian Islands, Int. Geol. Congr. Rep. Sess. 23rd, 1, 135-150, 1968.

Jackson, E. D., and T. L. Wright, Xenoliths in the Honolulu volcanic series, Hawaii, J. Petrol., 11, 405-530, 1970.

Julian, B. R., Regional variations in upper mantle structure beneath North America, Ph.D. thesis, 208 pp., Calif. Inst. of Technol., Pasadena, 1970.

Kitahara, S., S. Takenouchi, and G. C. Kennedy, Phase relations in the system $\mathrm{MgO}-\mathrm{SiO}_{2}-\mathrm{H}_{2} \mathrm{O}$ at high temperatures and pressures, Amer. $J$. Sci., 264, 223-233, 1966.

Kumazawa, M., H. Helmstaedt, and K. Masaki, Elastic properties of eclogite xenoliths from diatremes of the east Colorado plateau and their implications to the upper mantle structure, J. Geophys. Res., 76, 1231-1247, 1971.

Lovering, J. F., and A. J. R. White, Granulite and eclogite inclusions from basic pipes at Delegate, Australia, Contrib. Mineral. Petrol., 21, 9-52, 1969.

MacGregor, I. D., The effect of $\mathrm{CaO}, \mathrm{Cr}_{2} \mathrm{O}_{3}, \mathrm{Fe}_{2} \mathrm{O}_{3}$ and $\mathrm{Al}_{2} \mathrm{O}_{3}$ on the stability of spinel and garnet peridotites, Phys. Earth Planet. Interiors, 3, 372-377, 1970.

MacGregor, I. D., and J. L. Carter, The chemistry of clinopyroxenes and garnets of eclogite and peridotite xenoliths from the Roberts Victor mine, South Africa, Phys. Earth Planet. Interiors, 3, 391-397, 1970.

Mason, B., Composition of the earth, Nature, 211, 616-618, 1966.

McBirney, A. R., Compositional variations in Cenozoic calc-alkaline suites of Central America, Oreg. Dep. Geol. Miner. Ind. Bull., 65, 185-189, 1969.

McGetchin, T. R., The Moses Rock dike: Geology, petrology, and mode of emplacement of a kimberlite-bearing breccia dike, San Juan County, Utah, Ph.D. thesis, 405 pp., Calif. Inst. of Technol., Pasadena, 1968.

McGetchin, T. R., and L. T. Silver, Compositional relations in kimberlite from Moses Rock dike, San Juan County, Utah (abstract), Eos Trans. $A G U, 49,360,1968$.

McGetchin, T. R., and L. T. Silver, Compositional relations in minerals from kimberlite and related rocks from the Moses Rock dike, San Juan County, Utah, Amer. Mineral., 55, 1738-1771, 1970a.

McGetchin, T. R., and L. T. Silver, A crustalupper mantle model for the Colorado plateau based on observations of crystalline rock fragments in a kimberlite dike (abstract), Phys. Earth Planet. Interiors, 3, 471, $1970 b$.

McGetchin, T. R., L. T. Silver, and A. A. Chodos, Titanoclinohumite: A possible mineralogical site for water in the upper mantle, J. Geophys. Res., 75, 225-259, 1970.

McGetchin, T. R., Y. S. Nikhanj, and A. A. Chodos, Carbonatite-kimberlite relations in the Cane Valley diatreme, San Juan County, Utah, J. Geophys. Res., 78, in press, 1973.

Naeser, C. W., Geochronology of the NavajoHopi diatremes, Four Corners area, J. Geophys. Res., 76, 4978-4985, 1971.

Naeser, C. W., and D. Stuart-Alexander, The age and temperature of the Mule Ear diatreme, southeast Utah, Geol. Soc. Amer. Abstr. Prog., 155-156, 1969.

O'Hara, M. J., and E. L. P. Mercy, Eclogite, peridotite and pyrope from the Navajo country, Arizona and New Mexico, Amer. Mineral., 51, 336-352, 1966.

Pakiser, L. C., and R. Robinson, Composition of the continental crust as estimated from seismic observations, in The Earth beneath the Continents, Geophys. Monogr. Ser., vol. 10, edited by J. S. Steinhart and T. J. Smith, pp. 620-626, AGU, Washington, D.C., 1966.

Pakiser, L. C., and I. Zietz, Transcontinental crustal and upper mantle structure, Rev. Geophys. Space Phys., 3, 505-520, 1965.

Poldervaart, A., Chemistry of the earth's crust, in Crust of the Earth, Spec. Pap. 62, edited by A. Poldervaart, pp. 119-144, Geological Society of America, Boulder, Colo., 1955.

Porath, H., Magnetic variation anomalies and 
seismic low velocity zone in the western United States, J. Geophys. Res., 76, 2643-2148, 1971.

Press, F., Density distribution in the earth, Science, 160, 1218-1221, 1968.

Roller, J. C., Crustal structure in the eastern Colorado plateau province from seismic-refraction measurements, Bull. Seismol. Soc. Amer., $55,107-119,1965$.

Ronov, A. B., and A. A. Yaroshevsky, Chemical composition of the earth's crust, in The Earth's Crust and Upper Mantle, Geophys. Monogr. Ser., vol. 13, edited by P. J. Hart, pp. 37-57, AGU, Washington, D.C., 1969.

Roy, R. G., Heat flow measurements in the United States, Ph.D. thesis, 77 pp., Harvard Univ., Cambridge, Mass., 1963.

Roy, R. G., E. R. Decker, D. D. Blackwell, and F. R. Birch, Heat flow in the United States, $J$. Geophys. Res., 73, 5207-5221, 1968.

Sass, J. H., A. H. Lachenbruch, R. J. Monroe, G. W. Greene, and T. H. Moses, Jr., Heat flow in the western United States, J. Geophys. Res., 76, 6376-6413, 1971.

Shoemaker, E. M., Interpretation of lunar craters, in Physics and Astronomy of the Moon, edited by Z. Kopal, pp. 283-359, Academị, New York, 1962.

Sobolev, N. V., Eclogites and pyrope peridotites from the kimberlites of Yakutia, Phys. Earth Planet. Interiors, 3, 398-404, 1970.

Solomon, S. C., Seismic wave attenuation and partial melting in the upper mantle of North America, J. Geophys. Res., 77, 1483-1502, 1972.

Wagner, P. A., The evidence of the kimberlite pipes of the constitution of the outer part of the earth, S. Afr. J. Sci., 25, 197-148, 1928.

Wakita, H., H. Nagasawa, S. Uyeda, and H. Kuno, Uranium and thorium contents in ultrabasic rocks, Earth Planet. Sci. Lett., 2, 377-381, 1967.

Wasserburg, G. J., G. J. F. MacDonald, F. Hoyle. and W. A. Fowler, Relative contributions of uranium, thorium and potassium to heat production in the earth, Science, 143, 465-467, 1964.

Watson, K. D., Eclogite inclusions in serpentine pipes at Garnet ridge, northeastern Arizona, Geol. Soc. Amer. Bull., 71, 2082-2083, 1960.

Watson, K. D., Kimberlite pipes of northeastern Arizona, in Ultramafic and Related Rocks, edited by P. J. Wyllie, pp. 261-269, John Wiley, New York, 1967.

Watson, K. D., and D. M. Morton. Eclogite inclusions in kimberlite pipes at Garnet ridge, northeastern Arizona, Amer. Mineral., 54, 267$285,1969$.

White, R. W., Ultramafic inclusions in basaltic rocks from Hawaii, Contrib. Mineral. Petrol., 12, 245-314, 1966.

Williams, A. F., The Genesis of the Diamond, p. 636, Ernest Benn, London, 1932.

Williams, H., Pliocene volcanoes of the NavajoHopi country, Geol. Soc. Amer. Bull., 47, 111$172,1936$.

Wilshire, H. G., and R. A. Binns, Basic and ultrabasic xenoliths from volcanic rocks of New South Wales, J. Petrol., \&, 185-206, 1961.

(Received February 25, 1972; revised August 8, 1972.) 